\title{
The Role of Teachers in Task-Based Language Education
}

\author{
KRIS VAN DEN BRANDEN \\ KU Leuven \\ kris.VanDenBranden@arts.kuleuven.be
}

\section{A BSTRACT}

Both in the research literature on tasks and second language learning and in the pedagogical literature on task-based language teaching (TBLT), the role of the teacher has received scant attention. In this article, the role of the teacher in TBLT is approached from three perspectives: (a) the teacher as mediator of the students' language development, contributing to the effectiveness of TBLT as a pedagogical approach to second language education; (b) the teacher as a key figure in the implementation of TBLT, and thus as a change agent in the innovation of second language education; and (c) the teacher as researcher, and thus as an active contributor to the development and further refinement of TBLT as a researched pedagogy.

\section{INTRODUCTION}

Both in the research literature on tasks and second language learning and in the pedagogical literature on task-based language teaching (TBLT), the role of the teacher has received scant attention. In the domain of second language acquisition (SLA), research on tasks and language learning has primarily focused on establishing relationships between certain features of language tasks (such as their complexity, the type of information exchange involved, or the time pressure under which they need to be performed) and second language learners' performance and/or development. In the pedagogically oriented literature on TBLT, the central role of the learner tends to be highlighted: Learners are typically described as active agents who, through the performance of tasks, develop implicit and explicit second language knowledge and gradually become more proficient in comprehending and producing the target language for meaningful purposes. TBLT is defined as a "learner-centred approach to language teaching," which can be opposed to more traditional, "teacher-dominated" approaches (e.g., Van den Branden, Bygate, \& Norris, 2009, p. 3). Likewise, in publications that aim to establish links between the available SLA research literature and the pedagogical literature on second language education, the key terms describing the core of TBLT are "tasks" and "learners." For instance, Ellis and Shintani (2014, p. 135), in a recent volume called Exploring Language Pedagogy Through Second Language Acquisition Research, defined TBLT as an approach that "aims to develop learners' communicative competence by engaging them in meaning-focused communication through the performance of tasks." On the same page, they added that "a key principle of TBLT is that even though learners are primarily concerned with constructing and comprehending messages, they also need to attend to form for learning to take place." All this 
seems to suggest that learners are supposed to do tasks independently, with the teacher withdrawing as much as possible and language learning coming out as an almost natural result.

This is particularly striking in the light of the robust empirical research evidence that has accrued over the past 15 years, in which the crucial role of the teacher in instructed learning has been documented. On the basis of his extensive review of more than 800 meta-analyses on the impact of instruction on learning, Hattie (2012, p. 169) referred to teachers as "the major source of controllable variance" in an education system and as "the major players in the educational process" (p. 25). Similarly, in their analysis of the key features of education systems that successfully combine a concern for excellence (i.e., learners developing high levels of competence with regard to core subjects in the curriculum) with a concern for equity (i.e., all learners developing sufficiently high competence levels, irrespective of their social, cultural or linguistic background), McKinsey \& Company (2010) singled out the teacher as the most important factor enhancing educational effectiveness. Hence, they concluded: "The quality of an education system cannot exceed the quality of its teachers" (McKinsey \& Company, 2010, p. 16).

During the past few years, the above-mentioned research evidence has even led to a surge of popular media interest in the role of the teacher in education. For instance, in a widely quoted article in the journal The Atlantic, Richmond (2013) emphasized it is better to have a great teacher than a small class.

Clearly, not all teachers are equally effective. In this respect, the research into what distinguishes expert teachers (i.e., teachers who consistently achieve higherthan-average learning gains with their students) from experienced and novice teachers is highly informative. Several frameworks that describe the typical behaviors of expert teachers and that are based on extensive empirical evidence are now available (e.g., Danielson Group, 2013; Bill \& Melinda Gates Foundation, 2010; Grossman, Loeb, Cohen, \& Wyckoff, 2013; Hattie, 2012). By way of example, Table 1 describes the "7 C's" of the expert teacher, which were derived from the Measures of Effective Teaching Project (Bill \& Melinda Gates Foundation, 2010; see also Hattie, 2012). Based on a study in which more than 3,000 teachers were involved, and in which empirical links were established between student learning gains, observations of teacher's behavior in the classroom, and surveys of students' perceptions of good teaching, the 7 C's describe typical behaviors of expert teachers. Though other frameworks on effective teaching adopt a slightly different terminology, overall the $7 \mathrm{C}$ 's nicely capture the major findings that underpin the other existing frameworks.

By systematically integrating the $7 \mathrm{C}$ 's into the pedagogical decisions and actions they take, teachers can strongly enhance the learning that results from students' classroom activity. Much of this boils down to the fact that from the student's perspective, there may be a vast difference between doing (i.e., engaging in the performance of a task) and learning. In general, the term "learning" refers to people establishing relatively durable changes in their knowledge, skills, attitudes and competences (Dumont, Istance, \& Benavides, 2010; Hattie \& Yates, 2014). Even though people are capable of learning new things independently without the aid 
TABLE 1. The 7 C's Describing Effective Teacher Behavior

\begin{tabular}{|c|c|}
\hline 7 C's & Description \\
\hline Care & $\begin{array}{l}\text { The teacher gives the students the feeling that she or he really cares about them. The } \\
\text { teacher tries to understand how students feel about things. }\end{array}$ \\
\hline Challenge & $\begin{array}{l}\text { The teacher tries to make sure that the students learn a lot and expects full effort } \\
\text { from the students. The teacher asks the students to explain about the answers they } \\
\text { give. The teacher doesn't let students give up when the work gets hard. The } \\
\text { teacher wants the students to learn from their mistakes. }\end{array}$ \\
\hline Clarify & $\begin{array}{l}\text { The teacher explains difficult things clearly. The teacher has several good ways of } \\
\text { explaining each topic that is covered in class. When students don't understand } \\
\text { something, the teacher explains it another way. }\end{array}$ \\
\hline Captivate & $\begin{array}{l}\text { The teacher introduces topics and content that captivate the students' interest. The } \\
\text { teacher makes lessons enjoyable. The teacher tries to make sure that students do } \\
\text { not get bored. }\end{array}$ \\
\hline Confer & $\begin{array}{l}\text { The teacher gives the students ample opportunity to share their ideas and express } \\
\text { their thoughts. Students have a say in how things are done in class. The teacher } \\
\text { respects the students' suggestions and ideas. }\end{array}$ \\
\hline Consolidate & $\begin{array}{l}\text { The teacher checks to make sure the students understand what she or he is teaching. } \\
\text { The teacher gives feedback and useful comments on students' work and helps the } \\
\text { students understand how they improve their work and correct their mistakes. At } \\
\text { the end of the day or lesson, the teacher summarizes what the students have } \\
\text { learned. }\end{array}$ \\
\hline Control & $\begin{array}{l}\text { The teacher makes sure the class stays busy and doesn't waste time. Students treat } \\
\text { each other and the teacher with respect. }\end{array}$ \\
\hline
\end{tabular}

of other people, empirical research strongly indicates that there are clear limits to independent learning, especially with regard to the development of complex skills (such as the development of communicative competence in a second language) (Ellis \& Shintani, 2014; Hattie \& Yates, 2014). Learning often involves overcoming obstacles, correcting errors or misconceptions, refining behavior, building up new understandings, and revising commonly held beliefs. For this to occur, the (interactional) support of another person will often be helpful, decisive, and even crucial (Hattie \& Yates, 2014). In classrooms, support may come from peers (e.g., Mackey, 2007; Philp, Adams, \& Iwashita, 2014), but in many cases, the help of a more competent partner will be necessary. In second language classrooms, the teacher clearly stands out as the most competent partner of the learners involved.

All this is reflected in the pedagogically oriented literature on the role of the teacher in task-based language teaching (e.g., Devlieger \& Goossens, 2007; MüllerHartmann \& Schocker-von Ditfurth, 2011; Samuda, 2015; Van Avermaet, Colpin, Van Gorp, Bogaert, \& Van den Branden, 2006; Van den Branden, 2009b; Willis \& Willis, 2007). In what follows, I will first draw on these publications to describe what the role of the teacher in task-based classroom activity could look like. This section, then, will focus on the role of the teacher as a mediator of language learning, and thus on the potential role teachers can play to enhance the effectiveness of task-based language teaching. Next, I will discuss the empirical evidence that is available on what real teachers actually do when working with tasks. In this section, teachers are approached from their role as change agents, and thus as key figures in the actual implementation of TBLT. In a nutshell, the available research reveals that 
teachers' decisions and actions in authentic classroom practice may strongly differ from the prescriptions in the pedagogically oriented literature. What has become clear over the past 20 years is that most teachers are inclined to implement TBLT in ways they see fit. As such, they aim to give shape to an approach to language learning that is not only consistent with a particular view on language learning or with specific pedagogical guidelines, but that they themselves also experience as practicable, feasible and appropriate for the particular context in which they are functioning (Andon \& Eckert, 2009). In the final section of this article, I will describe a third perspective on the role of the teacher in TBLT: If we aim to expand the empirical base on the teacher as mediator of language learning and the teacher as change agent in ways that drive the TBLT field forward, more teachers will need to be actively involved in classroom-based research on task-based language learning and teaching (hence, the teacher as researcher).

\section{THE TEACHER AS MEDIATOR OF LANGUAGE LEARNING}

Drawing on the above-mentioned, pedagogically oriented literature on the role of the teacher in TBLT, the decisions and actions that teachers can (and according to some of these publications, should) take to optimally promote students' learning from the task-based work they engage in, will be described below. For the sake of clarity, I will categorize them into pretask, during-task, and posttask actions and decisions.

As for pretask actions and decisions (i.e., the ones teachers can, or should, take before they enter the classroom to teach a particular lesson or course), teachers may play a crucial role in selecting content and determining the focus of the classroom activity. Even though most teachers work in an institutional context in which guidelines with regard to (official) attainment targets, learning objectives, assessment procedures and even pedagogical approaches are issued, and many teachers also work with a commercial textbook or syllabus, the majority of teachers around the world retain a certain degree of autonomy. Among others, they get to decide (at least partly) which tasks and exercises the student will be exposed to, which text material will be covered, and which input the teacher will offer in their classroom. Moreover, in most cases, it is teachers who control the timeline of classroom activity: They decide how much time will be spent to each item on the agenda, how long a particular whole-class discussion will take, and how much time will be devoted to the performance of a particular task. It is teachers, too, who get to decide to which extent a focus on meaning and a focus on form will be balanced, and which particular forms will be highlighted, practiced, or covered explicitly. In other words, even if they are working with a task-based syllabus, it is teachers who design the task-as-workplan (Breen, 1989) for the next day in their classroom. In this respect, Long (2015) argued that in a task-based approach, teachers who select content and determine the focus of actual lesson activities should first and foremost be guided by an analysis of the students' second language learning needs, much 
more so than by the table of contents of the syllabus they use. This is demonstrated by the Flemish teacher in Example 1.

\section{Example 1. Teacher S. Planning a Task-Based Activity (adapted from Van den Branden, 2015b)}

Teacher S. is a teacher of Dutch as a second language at a Centre for Adult Education in Ghent (Belgium). She teaches a course of Dutch as a second language (DSL) to 12 students at beginner level. At the beginning of the course, she has asked the students about their main ambitions to learn Dutch and the most prominent language learning needs they have: What do they want to be able to do with the Dutch language in Dutch-speaking Flemish society? One of the most crucial needs that the students have in common is that they want to learn Dutch to function in Flemish society and to become more independent when dealing with public services or when they go shopping.

To cater for this particular need, teacher S. puts her regular syllabus aside and designs a lesson activity in which her students will have to leave the classroom and go shopping. She decides that she will provide her students with written street directions. Following these, the students will have to go to the bank to withdraw some cash (using the teacher's credit card), next to the baker's to buy bread and sweets for their teacher, and then on to the pharmacy to buy cheap but effective medicine for headaches. On their way, they also have to pop in at a local tourist office to try and find out more about the statue that is standing in front of the school building, and, finally, post a birthday card that the teacher is sending to her mum.

The teacher designs and copies the route instructions. A couple of days before the actual class takes place, she pays a visit to the baker's, pharmacist, and the woman working in the tourist office to prepare them for their conversations with a group of beginner DSL learners.

The next stage in which the teacher is active is the during-task-phase: This is when the task comes to life. The task-as-workplan (Breen, 1989) now turns into a task-in-action and a task-in-interaction. Van den Branden (2009b) emphasized that tasks as such do not determine learning. It is the intensity and quality of (a) the mental activity that students engage in while working with tasks (the actual efforts they put in reading, writing, speaking, listening, and coping with the input and output demands they are exposed to) and (b) the verbal interaction they build up with their peers and teachers that will determine the language learning that results from the task-based work. In this respect, teachers have at least three crucial roles to play:

The teacher remains a crucial interactional partner in task-based language classrooms, by taking the role of motivator (i.e., launching the students into action by constructing joint projects), organizer (making sure that students know what they are expected to do and organizing temporal and spatial aspects of task performance), and, last but 
not least, conversational partner and supporter, as the more proficient, knowledgeable interlocutor who can feed the language-learning needs of different students in a wide variety of ways. (Van den Branden, 2009b, p. 284)

Clearly, there are many links with the above-mentioned 7 C's here. As Dörnyei (2009) has suggested, motivating the students has to do with introducing tasks that the students find interesting, valuable, and relevant, on the one hand (captivate in the $7 \mathrm{C}$ 's), and which they find challenging yet doable, on the other hand (challenge in the 7 C's) (see also the article on learner engagement by Jenefer Philp in this volume). Clearly, there are a myriad of ways in which teachers can put this to practice, including actions such as highlighting the goals of the lesson, emphasizing the usefulness in real life of what the students will be learning, raising an interesting question, or pursuing a topic the students have introduced. In view of the fact that learning is something that teachers cannot do for learners and learners must actively invest energy in their own learning process, teachers have a crucial role in motivating and activating all learners. A study by Guilloteaux and Dörnyei (2008), involving 40 English as a second language classes and more than 1,300 students empirically corroborated that student motivation is related to teachers' motivational practices, and is, at the same time, correlated with student achievement. In this respect, Samuda (2015) saw the teacher's introduction of a task as the opening of a pedagogical space which the learners are eager to explore, and in which they can join the teacher in giving shape to the learning activity that unfolds.

This also requires a considerable amount of organizational actions from the teacher, such as providing clear task instructions, putting learners in groups, organizing turn-taking during whole-class discussions, maintaining control over what happens in the classroom (i.e., control in the $7 \mathrm{C}$ 's), all of which are not restricted to the introductory stage of a task-based lesson, but are a teacher's concern from the beginning of a task-based lesson to the very end (Devlieger \& Goossens, 2007; Willis \& Willis, 2007). As illustrated in Example 2, the teacher as organizer also has to make sure that the sequence of activities the learners engage in is logical, coherent, and is built up in such a way that learners are continuously exposed to challenges that remain doable.

\section{Example 2. Teacher S. Sequencing Activities That Gradually Become More Complex (adapted from Van den Branden, 2015b)}

Teacher S. (see Example 1) now moves into the during-task stage. Before the students are invited to leave the classroom and go shopping, teacher S. first asks them to get up, leave the classroom, and walk through the school building. Because she is fully aware that they are still at beginner level (they are just halfway their beginner course), she decides to freshen up the students' language skills related to street directions by giving individual students relatively easy directions that resemble route instructions, while the other students are allowed to observe and help the student (carrying out the instructions) if necessary. For instance, standing in the hallway just outside their classroom, teacher S. asks 
individual students to go straight on and stop at the third door on their right, to walk on and climb the stairs to their left. All students get a chance to practice, which results in a lot of recycling of relevant vocabulary and multiword units. Next, the group goes back to the classroom: the teacher asks one student who comes to school on foot to give her address. The teacher uses Google Street View to project the student's apartment on the whiteboard and then asks the student to describe the way she walks from home to school. The teacher follows up every direction she gets by following the route on Google Street View so that all students receive additional, visually supported input related to street directions. The teacher believes this introductory stage will raise chances that her students will be able to cope with the written street directions and not be overwhelmed (and frustrated) by them.

Next the students go shopping: they work in groups, so that they can interactionally support each other, and the teacher is right by their side all the time. She supports them while trying to comprehend the written street directions by negotiating for meaning; she practices the dialogues the students are supposed to have with the shopkeepers before they enter the shop, and encourages students to ask for additional information at the tourist office.

Afterwards, the teacher returns to the classroom to reflect on the streetbased (and authentic) tasks the students performed and the language that was used. She discusses all conversations the students had, focuses on a number of relevant and useful expressions and words, and invites the students to make explicit what they have learned.

The third major role of the teacher in the during-task stage (i.e., interactional partner and supporter), which is also illustrated in Example 2, has received the most attention in the pedagogically oriented literature (confer in the $7 \mathrm{C}$ 's). It tends to be associated with several actions the teacher can take to enhance the language learning potential of task-based work by raising the quantity and quality of interaction that occurs. Many of the actions a task-based teacher is supposed to take are directly linked to the research on the impact of interaction on second language development (e.g., Ellis, 2003; Ellis \& Shintani, 2014; Long, 2015; Mackey, 2007):

- The teacher should engage in the negotiation of meaning while the students try to deal with the input and output demands raised by the task (clarify in the $7 \mathrm{C}$ 's).

- The teacher should produce a wide variety of questions, cues, and prompts to elicit learner output.

- The teacher should provide feedback on the students' written and oral output. Feedback may come in different shapes, including explicit corrections, recasts, confirmation and clarification requests, metalinguistic comments, extensions, and elaborations (consolidate in the $7 \mathrm{C}$ 's).

- The teacher should incorporate a focus on form in the meaning-oriented work the students are doing. 
- The teacher should provide ample input and should model, or practice the performance of a task or the use of a certain strategy.

In Example 2, the teacher gets ample opportunity to put all these principles to practice and, by doing so, enrich the language learning environment the students are exposed to. For instance, after leaving a shop, she can negotiate the meaning of words used by the shopkeeper or briefly focus on forms that could have been used. Throughout the activity, she can monitor the students' progress and task performance on a minute-to-minute basis and provide them with supportive feedback while interacting with them or reflecting on their task performance (consolidate in the 7 C's). The teacher's feedback can be both implicit (e.g., the teacher recasting some of the students' utterances that they spontaneously produce while walking and looking around) and explicit (e.g., the teacher explicitly correcting errors students made while shopping).

Devlieger and Goossens (2007) emphasized that teachers should not only provide interactional support of a cognitive nature, but also provide socioemotional support to the students (care in the $7 \mathrm{C}$ 's). For instance, teachers should try to create a safe climate in which students do not feel overly anxious or inhibited to speak out and practice their productive skills, should treat all learners with respect, keep students motivated, give them positive feedback to enhance their well-being and self-confidence, and encourage them persist even if the task is difficult.

While doing so, teachers should try to differentiate between the individual learners in their classrooms (Van Avermaet et al., 2006). Since learning is a process that differs between individual learners (in view of the fact that individual students bring different prior knowledge, learning motivation, language learning needs, and interests to the activity), much of the teacher's role during task performance consists of monitoring the different students' task performance and tailoring input, feedback, and support to the immediate needs of specific learners on a second-tosecond basis:

Language teachers and learners feel, behave, and interact differently from day to day, and the language and tasks they work on vary, making every lesson unique. Global prescriptions and proscriptions, therefore, are unwarranted and doomed to failure. Teachers will have lesson plans, but they will need to react differently in real time to situations as they arise. (Long, 2015, p. 326)

After the performance of tasks, teachers may use the posttask stage to look back on the students' performance (e.g., the teacher in Example 2 discussing the dialogues in the shops with the students), focus on form, discuss particular strategies the students used, summarize the main lessons the students can draw from task performance, discuss specific questions or issues the students found themselves struggling with, and the like. In the posttask stage, too, teachers are expected to assess their learners' task performance and language development. This they can obviously do by making use of standardized, official tests or tests included in their syllabi, but teachers can also design (task-based) tests themselves 
or use their permanent observation and evaluation of students' task performance during regular class hours as the basis of their assessment and the feedback they provide. From a task-based perspective, teachers are expected to use meaningful tasks for assessment purposes, primarily evaluate whether students have performed the task to criterion (rather than focusing on the accurate production of a particular linguistic form) and use the assessment for formative purposes with a view to providing feedback to the learner (Long, 2015; Norris, 2009). From a task-based perspective, then, assessment mainly becomes instrumental in tailoring and finetuning further interactional support to the specific needs of (groups of) individual students, and in designing and revising what comes next in the course plan or curriculum accordingly (Norris, 2009; 2015; Van Avermaet et al., 2006).

\section{THE TEACHER AS CHANGE AGENT}

Over the past 25 years, teachers in a wide range of continents and educational contexts have been informed about TBLT and the role they are supposed to adopt within it. In regions like Flanders, Vietnam, and New Zealand, teachers have even been advised by their governments, pedagogical counselors, teacher educators, or inspectorates that TBLT is the preferred approach to language education:

The task-based approach has achieved something of the status of a new orthodoxy: teachers in a wide range of settings are being told by curriculum leaders that this is how they should teach, and publishers almost everywhere are describing their new textbooks as task-based. Clearly, whatever a task-based approach means, it is a good thing. (Littlewood, 2004, p. 319)

But do teachers actually use tasks? Do they fondly embrace "the new orthodoxy"? In 2001, Samuda stated that the extent to which teachers actually realized their role as a mediating factor in task-based language teaching remained "virtually unexamined" (Samuda, 2001, p. 119). Since then, however, a steadily growing body of empirical evidence, collected in a wide variety of teaching contexts and across different continents, has accrued, vividly documenting the ways in which teachers perceive TBLT and work with tasks in their classrooms (e.g., Andon \& Eckert, 2009; Carless, 2004; East, 2012; Edwards \& Willis, 2005; Ellis, 2015; McDonough, 2015; McDonough \& Chaikitmongkol, 2007; Müller-Hartmann \& Schocker-von Ditfurth, 2011; Samuda, 2001; Samuda \& Bygate, 2008; Shehadeh \& Coombe, 2012; Van den Branden, 2006, 2009b, 2015a; Van den Branden, Van Gorp, \& Verhelst, 2007; Van Gorp \& Van den Branden, 2015). The available research, most of which combines the observation of teachers in their classrooms with teacher interviews or surveys reveals that there is a clear tension between TBLT as a principled approach (as described in the above-mentioned pedagogically oriented publications) and TBLT as it takes shape in authentic educational practice. 
On the whole, teachers do not "follow 'official' TBLT-related pedagogic recommendations in a slavish way" (Andon \& Eckert, 2009, p. 305). Across different educational contexts and with courses addressing learners at different proficiency levels, teachers have been shown to modify tasks developed by professional syllabus developers, and the task-based approach on the whole, to suit their own beliefs on what constitutes good education, their perceptions of their students' needs, and the demands and features of the context they are operating in. The range and nature of the modifications teachers make while working with tasks, and which could be regarded as deviations from the above-mentioned pedagogical guidelines, is wide and varied, and includes (among others) the following:

- Modifying the complexity of written and oral input the learners are exposed to (e.g., simplifying challenging input)

- Increasing the degree to which explicit focus on form, and the isolated practice on particular linguistic structures and forms, constitutes an essential part of the lesson

- Replacing group and pair work with whole-class discussions

- Relegating work on communicative tasks to the final stages of the lesson (i.e., turning the task-based lesson into a task-supported activity or even a forms-focused lesson)

Teachers have various reasons for doing so, but ultimately, the available research makes clear that teachers' classroom practice and beliefs are not dictated by the publications produced by SLA researchers or language pedagogues. Rather, teachers are guided by their own "personalized, context-sensitive and practically oriented networks of educational beliefs and practice" (Borg, 2006, p. 81), which are primarily fed by their own experiences as a student and a practicing teacher (Van den Branden, 2009a). Most of the studies mentioned above included not only classroom observations but also interviews with teachers that revealed what teachers thought about the pedagogical principles underpinning TBLT and the syllabi they were supposed to be working with. Clearly, most teachers have mixed feelings. Among the major benefits that practicing teachers have been found to be associated with TBLT are the following (East, 2012; Edwards \& Willis, 2005; McDonough, 2015; Müller-Hartmann \& Schocker-von Ditfurth, 2011; Shehadeh \& Coombe, 2012; Van den Branden, 2006, 2009a):

- Task-based work and grouping formats, such as group work and pair work, which are a key feature of the approach, give students extensive opportunities to practice and develop their communicative skills. In particular, TBLT is useful for the development of speaking skills and for learners to increase the fluency, complexity, and accuracy of their spoken output.

- Task-based work helps students to build more self-confidence to use the target language (both inside and outside the classroom).

- Tasks are fun for learners and may enhance their language learning motivation in class.

- Tasks can be rewarding for learners because the students have to work toward a clear goal. 
- Task-based work reaches beyond language learning: It offers learners the opportunity to develop self-regulation skills, problem-solving skills, intercultural competence, and social skills.

However, teachers have also raised a wide range of critical concerns with a task-based approach to language teaching (Carless, 2004, 2012; East, 2012; McDonough, 2015; Shehadeh \& Coombe, 2012; Van den Branden, 2006; Zhang, 2007):

- A task-based approach with its primary focus on meaning-making may clash with (a) official, standardized, and form-focused tests that students are supposed to prepare for; (b) the crucial importance that teachers assign to the development of explicit (grammatical) knowledge and a primary concern for accuracy of output; and (c) teachers' beliefs that the development of communicative language skills is based on the preceding development of explicit knowledge.

- Task-based work, with its strong emphasis on learner initiative, may decrease the degree of control the teacher wants to maintain over what happens in the classroom.

- Peer interaction during task-based work may lead to increased levels of noise in the classroom and to an increased use of the students' mother tongue.

- It is very difficult to implement a task-based approach in large classes.

- The emphasis on learner initiative, autonomy, and independence conflicts with more hierarchical views of the student-teacher relationship and with the role of the teacher as expert and superior.

All this illustrates that the implementation of a task-based approach to language teaching is a slow and complex endeavor, even in contexts where TBLT is propagated by governments and official educational bodies and where teachers are provided with task-based syllabi. The above-mentioned research results have alerted applied linguists, second language researchers, and pedagogues that, when it comes to the implementation of TBLT, as much as with any other educational innovation (Fullan, 2011), it is the positive energy and engagement of teachers and their learners that drive the process forward, on the one hand, and the conflicts between features of the approach and teachers' or learners' concerns that slow it down, on the other hand. So, as much as with any other educational innovation, the implementation of TBLT will only move forward to the extent that teachers find personal value and reward in adopting the approach, can integrate it in their networks of educational beliefs and practice, and are convinced that the approach will be beneficial for their learners' development and their own functioning as teachers. In this respect, it may be more productive to regard the so-called deviations from the prescriptions in the pedagogically oriented literature on TBLT as either the intermediary steps teachers have to take in the process of implementing TBLT or as the manifestations of what an approach like TBLT actually looks like, or can look like, once it enters real classrooms and becomes the stuff that real learners and teachers in authentic educational contexts work with (East, 2012; Samuda, 2015; Van den Branden, 2015a). From this perspective, the major goal of theory and research into SLA, on the one hand, and of the pedagogical literature on TBLT, 
on the other, is "not to direct teachers how to teach, but rather to advance a number of 'provisional specifications' that teachers can then try out, adapting them to their own particular teaching contexts" (Ellis, 2003, p. x).

Studies in which teachers working with tasks are followed up over a longer period, such as the studies done in Flanders (Van den Branden, 2006), New Zealand (East, 2012), and Germany (Müller-Hartmann \& Schocker-von Ditfurth, 2011), strongly indicate that for teachers the implementation of TBLT is a gradual process of learning, which needs to go through repeated cycles of trying out, reflecting, revising, and trying out again, to allow the teachers to gain confidence and develop the professional expertise that is needed to raise the learning potential of task-based work (e.g., Norris, 2015). As much as learners need interactional support to learn from task-based work, language teachers who start working with tasks similarly need such support. This type of interactional support and guidance will help teachers develop the expertise and the confidence to use tasks to optimally promote their students' target language development and overcome some of the doubts and concerns that they typically have in the first stage of adoption. Implementing TBLT and making it work for all learners in a classroom is a complex skill (Müller-Hartmann \& Schocker-von Ditfurth, 2011): Teachers cannot be expected to develop these skills independently, automatically, and immediately. The development of taskbased syllabi and the provision of one-shot, inservice training sessions have been found to have a very limited effect on teachers' beliefs and practices (Van den Branden, 2006). A growing body of empirical research evidence indicates that much more can be expected from the kind of coaching that takes place on the work floor (i.e., in the teachers' schools and classrooms), is tailored to the teachers' personal interests, questions, and worries; is classroom-based; alternates between action and reflection; and allows teachers sufficient time to develop the required professional expertise (East, 2012; Müller-Hartmann \& Schocker-von Ditfurth, 2011; Van den Branden, 2009a).

\section{THE TEACHER AS RESEARCHER}

TBLT was launched more than 30 years ago as a principled approach to language teaching. As mentioned above, TBLT has gained much ground among those who regard the teaching of second and foreign languages from a theoretical, researchbased, or educational policy perspective. But the ultimate question that should be raised (and this applies to TBLT as much as to any other approach to language education) is: Does the approach work for both teachers and students in real classrooms? Does it enhance the language learning of the students involved? Does TBLT make a difference for people in real life?

At this stage, these crucial questions remain partly unanswered. This primarily has to do with the fact that there is very little empirical research available in which the impact of task-based educational programs on the language development of students has been documented (for an overview, see Norris, 2015). Most of the research in the SLA domain in which researchers invite students to work with tasks 
were conducted in laboratory settings. Students are typically taken out of their classrooms, work with tasks outside regular class hours, and/or are being taught by trained professionals who are not their regular teachers. In addition, most of this research involves university-level students; there is much less research available in which children, adolescents, and low-educated adults are involved. The number of tasks students are asked to work with is very limited in most studies, the duration of the treatment quite limited, and the focus of study is narrow (e.g., the impact of working with a few tasks on the acquisition of a particular grammar item). In addition, many studies focus on performance rather than development (e.g., most of the studies are aimed at establishing a link between the complexity of a task and the complexity, accuracy, and fluency of the output learners produce). Altogether, it remains unclear to what extent the results of these laboratory studies can be extrapolated to natural classroom conditions.

The range of studies is limited in which students were actually enrolled in a task-based course or program and were followed over a longer period to establish the impact of the program on the students' language development. None of the programs listed by Norris (2015) and which included an evaluation of teacher's classroom behavior and a longitudinal assessment of students' language development "can be considered a true experimental design in which TBLT could be causally linked to learning gains" (p. 51). But, Norris added on the same page, "that is a virtual impossibility for evaluation of any actual intervention that takes place on an educational-programmatic scale." For one, the research mentioned in the previous section suggests that there are very few, if any, teachers in the world who implement a rigorous, task-based approach in each of their lessons all the time. Virtually all studies reported in the previous section indicate that regular teachers adopt an eclectic approach to language teaching, combining task-based work with educational actions and decisions, which may be ascribed by theorists to quite different approaches. Moreover, regular teachers dynamically adapt their eclectic approach depending on their learners' needs, the topic they are covering, the learning goals they are pursuing, and the demands raised by the societal, educational, and institutional context in which they find themselves. This results in considerable within-teacher variation (across different lesson activities and student groups) and between-teacher variation (i.e., between the teachers operating in the same educational system or even school), which virtually turns the study of the exact impact of a so-called task-based educational program on the students' second language development into a methodological nightmare. But if this is true, then the methodological nightmare might, in its turn, render the implementation of TBLT into a daring challenge: how to convince teachers of the potential surplus value of TBLT if its effects in authentic classroom environments are uncertain?

Much, however, depends on how the notion of "TBLT as a researched pedagogy" is approached. If, broadly speaking, a pedagogy aims to offer teacher guidelines on how to teach a particular subject, then there are different ways in which a pedagogy could be researched. A more or less prescriptive reading of the term would imply that the pedagogical guidelines that are suggested are all based on research-for instance, the kind of research that documents how people acquire the competences 
related to the subject at hand. For TBLT, this means that the pedagogical guidelines associated with a task-based approach should be primarily based on research into SLA: Whatever specific guidelines or provisional specifications are suggested, they should at the very least be consistent with what we know about SLA (e.g., Ellis \& Shintani, 2014). Much of the pedagogical recommendations and methodological principles that have been published with regard to TBLT so far, though widely differing in terms of how specific and concrete they aim to be, seem to follow that line of reasoning (e.g., Long, 2015; Ellis, 2003; Van den Branden, 2006).

From the perspective of the language teacher, however, such pedagogical guidelines raise at least two major concerns. First, although the available research into SLA has yielded a large number of pieces of the jigsaw puzzle (e.g., the research on negotiation of meaning; focus on form; task performance; and the complexity, accuracy, and fluency of second language learners' output), the overall holistic picture remains unclear. To date, there is no unified theory of SLA. On the contrary, a number of theoretical paradigms seem to be competing with each other, and as a result the pedagogical guidelines underpinning TBLT have been pieced together in different ways by different authors. Second, to date it remains unclear to what extent the available research into SLA is context-sensitive: What, in other words, do laboratory-type studies in SLA, even when tasks are involved, have to say about the way students learn a language in an authentic second language classroom? To what extent are the motivations, drives, actions, interactions, decisions, negotiation, and attentional processes of the teachers and students in all these SLA-related studies comparable to those they typically exhibit during regular classroom hours?

A more descriptive reading of a "researched pedagogy" would make the main focus of research be the pedagogical actions and decisions that are actually taken by teachers and students in authentic classrooms while they are working with tasks. The main unit of analysis of this research, then, would be the task-in-action, starting from the basic notion that a task is a goal-oriented activity that involves the meaningful use of language (e.g., Long, 2015; Ellis, 2003; Van den Branden, 2006), in order to distinguish task-based work from other types of exercises in the language classroom. Classroom-based research into tasks-in-action, then, could include virtually any actual use teachers and students make of tasks in authentic classrooms. This could lead to a wide range of studies that, among others, dig into the following issues (separately or in combination):

- Which beliefs do teachers hold about the tasks they are (supposed to be) working with? What do they think about their learning potential and about possible ways to raise their learning potential?

- What drives teachers to work with particular tasks, and what holds them back?

- How do teachers make use of tasks in their classrooms?

- How do teachers build a task-based (or task-supported) lesson? Why do they do so? How do they build a task-based course? How do they sequence tasks, and why do they do so?

- How do students react to teachers' approach of classroom-based work with tasks?

- Which variables influence the students' and teachers' perceptions about tasks and their motivations to work with tasks? 
- Which interaction patterns (between students, and between students and teachers) unfold in authentic classrooms depending on the way tasks are used?

- What is the impact of a particular sequence of task-based activities, or a particular implementation of tasks (over a longer period) on the SLA of the students in the classrooms involved?

- Which types of task-based work do students consider the most effective? Which actions of their teachers (during task-based work) do they consider the most effective?

- Which types of learners profit most from particular types of classroom-based work with tasks?

- How do the results of the above-mentioned studies feed a theory of instructed (taskbased) language learning?

In this type of research, teachers can adopt different roles. Apart from the role of mediator of the students' language learning and change agent in the implementation of TBLT, they can also act as action researchers and reflective practitioners (Burns, 2009; Pollard, 2014). They can gather data, analyze them, share the results of their (action) research with applied linguists and university-based researchers, pool their resources with other teachers, and reflect on the theoretical implications of their research findings. By video- or audiotaping their lessons or their colleagues' lessons, they can extend the available pool of data on authentic, taskbased classroom interaction to a considerable extent. By engaging their students to fill out surveys to evaluate task-based lessons and having them take standardized, curriculum-independent tests, teachers can contribute to a steadily growing database that could form the basis of the kind of research that, in the abovementioned Measures of Effective Teaching Project, led to the $7 \mathrm{C}$ 's described in this article.

What I have called "prescriptive" and "descriptive" research strands are not mutually exclusive. To really move forward, and to deepen our insights into instructed language learning, we probably need both. Since both Long (2015) and Ellis (2003) have stressed that the pedagogical guidelines issued by applied linguists on the basis of SLA research can only be provisional and are not meant to be considered as global prescriptions, classroom-based research will be crucial to make the potential impact of TBLT in specific contexts for specific types of learners more concrete and tangible. In this respect, Van Gorp and Van den Branden (2015) used multilevel analysis to determine the learning gains of primary school children (i.e., second language learners of Dutch) in a 1-week, task-based science project combining science and language learning. They used the results of the statistical analysis so single out children who made exceptional learning gains, and then adopted microgenetic discourse analysis to explore the contribution that the teacher made to these children's progress through his interactional support. This study indicated that for young children, the impact of the teacher in task-based work is strongly mediated by the socioemotional relationship between teacher and child, the child's interest in the topic, and the child's assertiveness. These variables may, in other words, enhance or reduce the impact of scaffolding, negotiation moves, recasting, and other types of interactional support offered by the teacher to the child during task-based work. 


\section{CONCLUSIONS}

As much as in a so-called traditional, teacher-dominated approach language teaching, the role of the teacher in TBLT is crucial. Teachers bring TBLT to life. They have a pivotal role in planning and designing lesson activities that are tailored to their students' internal syllabi. They are crucial when it comes to providing target language input and eliciting the kind of language use and form-focus that provides second language learners with optimal opportunities to practice and develop their language skills. By participating in task-based dialogue, they can model target language use and interactionally support their learners. By organizing classroom activity efficiently and motivating their students, they can increase the likelihood that every single student will approach the task in an active way and learn from it. In line with the available research on the impact of the teacher on instructed learning, it could be hypothesized, then, that the quality of TBLT cannot exceed the quality of the teachers working with tasks.

Therefore, in research on task-based learning, teachers should receive much more attention. Research needs to highlight the concerns that teachers have with the tasks they are exposed to and are working with. Research needs to document the interaction and the real life in classrooms that tasks give rise to, in an attempt to link them to the instructed language learning that results. Involving teachers as full-blown (action) researchers could be a particularly promising way of increasing their involvement with TBLT as key agents in the implementation of the approach and, at the same time, allowing them to gain more insight in the exact ways in which they can use and exploit tasks to optimally promote their students' second language learning.

\section{REFERENCES}

Andon, N., \& Eckert, J. (2009). Chacun à son gout. Task-based L2 pedagogy from the teacher's point of view. International Journal of Applied Linguistics, 19, 286-310.

Bill \& Melinda Gates Foundation. (2010). Learning about teaching: Initial findings from the Measures of Effective Teaching Project. Retrieved from http://www.metproject.org/downloads/ Preliminary_Findings-Research_Paper.pdf

Borg, S. (2006). Teacher cognition and language education: Research and practice. London, UK: Continuum.

Breen, M. (1989). The evaluation cycle for language learning tasks. In R. Johnson (Ed.), The Second Language Curriculum (pp. 187-206). Cambridge, UK: Cambridge University Press.

Burns, A. (2009). Action research in second language teacher education. In A. Burns \& J. C. Richards (Eds.), The Cambridge guide to second language teacher education (pp. 289-297). New York, NY: Cambridge University Press.

Carless, D. (2004). Issues in teachers' re-interpretation of a task-based innovation in primary schools. TESOL Quarterly, 38, 389-396.

Carless, D. (2012). TBLT in EFL settings. Looking back and moving forward. In A. Shehadeh \& C. Coombe (Eds.), Task-based language teaching in foreign language contexts (pp. 345-358). Amsterdam, The Netherlands: John Benjamins.

Danielson Group. (2013). The 2013 Framework for Teaching Evaluation Instrument. Princeton, NJ: The Danielson Group.

Devlieger, M., \& Goossens, G. (2007). An assessment tool for the evaluation of teacher practice in powerful task-based language environments. In K. Van den Branden, K. Van Gorp, \& M. Verhelst (Eds.), Tasks in action: Task-based language education from a classroom-based perspective (pp. 92130). Newcastle, UK: Cambridge Scholars. 
Dörnyei, Z. (2009). The psychology of second language acquisition. Oxford, UK: Oxford University Press.

Dumont, H., Istance, D., \& Benavides, F. (Eds.). (2010). The nature of learning. Using research to inspire practice. Paris, France: OECD.

East, M. (2012). Task-based language teaching from the teachers' perspective. Amsterdam, The Netherlands: John Benjamins.

Edwards, C., \& Willis, J. (2005). Teachers exploring tasks in English language teaching. Hampshire, UK: Palgrave Macmillan.

Ellis, R. (2003). Task-based language learning and teaching. Oxford, UK: Oxford University Press.

Ellis, R. (2015). Teachers evaluating tasks. In M. Bygate (Ed.), Domains and directions in the development of TBLT (pp. 248-270). Amsterdam, The Netherlands: John Benjamins.

Ellis, R., \& Shintani, N. (2014). Exploring language pedagogy through second language acquisition research. New York, NY: Routledge.

Fullan, M. (2011). Choosing the wrong drivers for whole system reform. Melbourne, Australia: Centre for Strategic Education.

Guilloteaux, M., \& Dörnyei, Z. (2008). Motivating language learners: A classroom-oriented investigation of the effects of motivational strategies on student motivation. TESOL Quarterly, 42, 5577.

Grossman, P., Loeb, S., Cohen, J., \& Wyckoff, J., (2013). Measure for measure: The relationship between measures of instructional practice in middle school English language arts and teachers' value-added scores. American Journal of Education, 119(3), 445-470.

Hattie, J. (2012). Visible learning for teachers: Maximizing impact on learning. New York, NY: Routledge.

Hattie, J., \& Yates, G. (2014). Visible learning and the science of how we learn. New York, NY: Routledge.

Littlewood, W. (2004). The task-based approach: some questions and suggestions. ELT Journal, 58(4), 319-326.

Long, M. (2015). Second language acquisition and task-based language teaching. Sussex, UK: WileyBlackwell.

Mackey, A. (2007). Conversational interaction in second language acquisition. Oxford, UK: Oxford University Press.

McDonough, K. (2015). Perceived benefits and challenges with the use of collaborative tasks in EFL contexts. In M. Bygate (Ed.), Domains and directions in the development of TBLT (pp. 225-245). Amsterdam, The Netherlands: John Benjamins.

McDonough, K., \& Chaikitmongkol, W. (2007). Teachers' and learners' reactions to a task-based EFL course in Thailand. TESOL Quarterly, 41, 107-132.

McKinsey \& Company. (2010). How the world's best-performing school systems come out on top. London, UK: Author.

Müller-Hartmann, A., \& Schocker-von Ditfurth, M. (2011). Task-supported language learning. Paderborn, Germany: Verlag Ferdinand Schöningh.

Norris, J. (2009). Task-based teaching and testing. In In M. Long \& C. Doughty (Eds.), The handbook of language teaching (pp. 578-594). Oxford, UK: Blackwell.

Norris, J. (2015). Thinking and acting programmatically in task-based language teaching. In M. Bygate (Ed.), Domains and directions in the development of TBLT (pp. 27-57). Amsterdam, The Netherlands: John Benjamins.

Philp, J., Adams, R., \& Iwashita, N. (2014). Peer interaction and second language learning. New York, NY: Routledge.

Pollard, A. (2014). Reflective teaching in schools (4th ed.). New York, NY: Bloomsbury Academic.

Richmond, E. (2013). Is it better to have a great teacher than a small class? The Atlantic. Retrieved from http://www.theatlantic.com/education/archive/2013/11/is-it-better-to-have-a-great-teacher-or-asmall-class/281628/

Samuda, V. (2001). Guiding relationships between form and meaning during task performance: The role of the teacher. In M. Bygate, P. Skehan, \& M. Swain (Eds.), Researching pedagogic tasks: Second language learning, teaching and testing (pp. 119-140). Harlow, UK: Longman.

Samuda, V. (2015). Tasks, design, and the architecture of pedagogical spaces. In M. Bygate (Ed.), Domains and directions in the development of TBLT (pp. 271-301). Amsterdam, The Netherlands: John Benjamins.

Samuda, V., \& Bygate, M. (2008). Tasks in second language learning. New York, NY: Palgrave Macmillan. 
Shehadeh, A., \& Coombe, C., (Eds.). (2012). Task-based language teaching in foreign language contexts. Amsterdam, The Netherlands: John Benjamins.

Van Avermaet, P., Colpin, M., Van Gorp, K., Bogaert, N., \& Van den Branden, K. (2006). The role of the teacher in task-based language teaching. In K. Van den Branden (Ed.), Task-based language teaching: From theory to practice (pp. 175-196). Cambridge, UK: Cambridge University Press.

Van den Branden, K. (Ed.) (2006). Task-based language education: From theory to practice. Cambridge, UK: Cambridge University Press.

Van den Branden, K. (2009a). Diffusion and implementation of innovations. In M. Long \& C. Doughty (Eds.), The handbook of language teaching (pp. 659-672). Oxford, UK: Blackwell.

Van den Branden, K. (2009b). Mediating between predetermined order and complete chaos. The role of the teacher in task-based language education. International Journal of Applied Linguistics, 19(3), 264-285.

Van den Branden, K. (2015a). Task-based language education. From theory to practice... and back again. In M. Bygate (Ed.), Domains and directions in the development of TBLT (pp. 303-320). Amsterdam, The Netherlands: John Benjamins.

Van den Branden, K. (2015b, September). Tasks for real! Hang on, how real is "real"? Plenary lecture delivered at the Sixth International Conference of Task-Based Language Teaching, Leuven, Belgium.

Van den Branden, K., Bygate, M., \& Norris, J. M. (Eds.). (2009). Task-based language teaching: A reader. Amsterdam, The Netherlands: John Benjamins.

Van den Branden, K., Van Gorp, K., \& Verhelst, M. (2007). Tasks in action: Task-based language education from a classroom-based perspective. Cambridge, UK: Cambridge Scholars.

Van Gorp, K., \& Van den Branden, K. (2015). Teachers, pupils and tasks: The genesis of dynamic learning opportunities. System, 54, 28-39.

Willis, J., \& Willis, D. (2007). Doing task-based teaching: A practical guide to task-based teaching for ELT training courses and practicing teachers. Oxford, UK: Oxford University Press.

Zhang, E. (2007). TBLT-innovation in primary school English language teaching in mainland China. In K. Van den Branden, K. Van Gorp, \& M. Verhelst (Eds.), Tasks in action. Task-based language education from a classroom-based perspective (pp. 68-91). Cambridge, UK: Cambridge Scholars. 